\title{
Improving Biosafety in Performing Haematology Practicals
}

\author{
Mahantayya Math, Rita Khadkikar, Yashoda Kattimani, Swati Gawali, Priyanka Rane, Madhur Rai, Ravindra \\ Inamdar
}

\section{Mahantayya Math*, Rita \\ Khadkikar, Yashoda Kattimani, Swati Gawali, Priyanka Rane, Madhur Rai, Ravindra Inamdar}

Department of Physiology, MGM Medical College, Navi Mumbai, Maharashtra, INDIA.

\section{Correspondence}

Mahantayya Math

Associate Professor, Department of Physiology, MGM Medical College, Navi Mumbai-410209, Maharashtra, INDIA.

Phone: +91-9619819864

Email: mathmv@rediffmail.com

\section{History}

- Submission Date: 20-06-2019

- Review completed: 14-07-2019;

- Accepted Date: 31-07-2019.

DOI : 10.5530/ijcep.2019.6.2.19

\section{Copyright}

(C) 2019 Phcog.Net. This is an openaccess article distributed under the terms of the Creative Commons Attribution 4.0 International license.
Sir,

At present hematology practicals in India are performed by medical, dental and paramedical students. Mouth pipetting is done in hematology practicals and primary health centres and small hospitals to do hemoglobin determination, total red blood cell count (total RBC count), total white blood cell count (total WBC count) and platelet count.

The physiology practical manuals describe the use of Haemoglobin pipette, WBC pipette and RBC pipette. ${ }^{[1-4]}$ The pipette for haemoglobin determination has a rubber tubing and mouth piece to help in collecting required amount of blood. The pipettes for Total WBC count and Total RBC count have glass bulb for mixing blood with dilution fluid and rubber tube is attached to pipette with mouth piece to collect the blood sample and dilution fluid.

Recently we have shown that haemoglobin determination, Total WBC count and Total RBC count, can be done with haemoglobin pipette only without mouth pipetting and blood sample is collected with the help of haemoglobin pipette with rubber bulb. ${ }^{[5]}$ Dilution is done with the help of glass bottle top dispenser. It is easier to do mixing in a test tube. This helps to get accurate results for RBC count, WBC count and platelet count as 20 microliters of blood sample is collected and dilution (with glass bottle top dispenser or $1 \mathrm{ml}$ and $5 \mathrm{ml}$ syringes) is done in test tube (dilution for WBC count is $1: 21$, dilution for $\mathrm{RBC}$ count and platelet count is 1: 201) Charging errors are also minimal as glass capillary is used for charging the Neubauer chamber
According to Laboratory biosafety manual of World Health Organization mouth pipetting should be avoided and pipetting aids must be used. ${ }^{[6]}$

This method is easy and gives better biosafety as it avoids mouth pipetting (rubber bulb is used as pipetting aid) for collection of blood sample and diluting fluid. This method has accurate dilution and minimal charging errors. ${ }^{[5]}$

Hence we suggest that this new method can be used in performing haematology practicals in physiology and also in primary health centres and small hospitals.

\section{REFERENCES}

1. Ghai CL. A textbook of practical physiology. $8^{\text {th }}$ edition. New Delhi: Jaypee Brothers Medical Publishers (P) Ltd., 2013;60-9.

2. Pal GK, Pal P. Textbook of practical physiology. $4^{\text {th }}$ edition Hyderabad: Universities Press (India) Pvt Ltd., 2017.

3. Reddy LP. Practical physiology. $2^{\text {nd }}$ edn. New Delhi: Paras Medical Publisher, 2009;25-8.

4. Jain AK, Manual of Practical Physiology for MBBS $6^{\text {th }}$ edition 2019 As Per Revised MCl Curriculum 2019 Arya Publications, New Delhi

5. Math MV, Khadkikar RM, Kattimani YR, Padhye M, Gawali SR, Rai M. A Safe and Easy Method for Hematology Practicals. MGM J Med Sci. 2019;6(1):48-50.

6. Laboratory biosafety manual. World Health Organization. $3^{\text {rd }}$ edition. Geneva 2004. (Part I biosafety guide lines 3. Basic laboratories - Biosafety Levels 1 and 2) https://www.who.int/csr/resources/publications/biosafety/Biosafety7.pdf 